\title{
Validation of gravity data from the geopotential field model for subsurface investigation of the Cameroon Volcanic Line (Western Africa)
}

\author{
Jean Marcel ${ }^{1,3}$, Jean Marcel Abate Essi ${ }^{2,4^{*}}$, Philippe Njandjock Nouck ${ }^{3}$, Oumarou Sanda ${ }^{1,5}$ \\ and Eliézer Manguelle-Dicoum ${ }^{3}$
}

\begin{abstract}
Belonging to the Cameroon Volcanic Line $(\mathrm{CVL})$, the western part of Cameroon is an active volcanic zone with volcanic eruptions and deadly gas emissions. The volcanic flows generally cover areas and bury structural features like faults. Terrestrial gravity surveys can hardly cover entirely this mountainous area due to difficult accessibility. The present work aims to evaluate gravity data derived from the geopotential field model, EGM2008 to investigate the subsurface of the CVL. The methodology involves upward continuation, horizontal gradient, maxima of horizontal gradient-upward continuation combination and Euler deconvolution techniques. The lineaments map inferred from this geopotential field model confirms several known lineaments and reveals new ones covered by lava flows. The known lineaments are interpreted as faults or geological contacts such as the Foumban fault and the Pan-African Belt-Congo craton contact. The lineaments highlighted coupled with the numerous maar lakes identified in this volcanic sector attest of the vulnerability of the CVL where special attention should be given for geohazard prevention.
\end{abstract}

Keywords: Cameroon Volcanic Line, Subsurface, Gravity data, Lineaments

\section{Introduction}

The Cameroon Volcanic Line (CVL), also called the Cameroon Line (Ngako et al. 1991) or Cameroon Hot Line (Nkono et al. 2014), is made up of an alignment of mountains trending $\mathrm{N}^{\circ} 0^{\circ}$ and is divided into two parts: an oceanic part with volcanic islands of Gulf of Guinea and a continental part characterized by volcanic eruptions of Mount Cameroon and deadly gas emissions from lakes Monoun in 1984 and Nyos in 1986, respectively (Fig. 1). The volcanic activities observed in this continental part (lava flows, pyroclastic rocks and plugs) dates back to about $30 \mathrm{Ma}$ (Dunlop and Fitton 1979). Several geological and geophysical studies have been carried out along the CVL to understand its structure, origin and evolution.

\footnotetext{
*Correspondence: abatemarcel@yahoo.fr

${ }^{2}$ Institute for Geological and Mining Research, PO Box 333, Garoua, Cameroon

Full list of author information is available at the end of the article
}

The main gravity surveys in Central Africa especially were carried out by Collignon (1968), Poudjom-Djomani (1993), Poudjom-Djomani et al. (1996) and Nnange et al. (2000). Poudjom-Djomani (1993) and Marcel et al. (2010) have used these terrestrial gravity data to investigate the internal structure of the CVL and suggested a general asthenospheric uplift. Marcel et al. (2016) used gravity data derived from EGM2008 to investigate the depth of Moho discontinuity under the CVL and found values ranging from 19 to $34 \mathrm{~km}$. From seismic data, Koch et al. (2012) interpreted lattice-preferred orientation frozen into the Congo Craton and subcontinental lithosphere related to relict plate motion and deformation. Moreau et al. (1987) and Nkono et al. (2014) used remote sensing and deduced the general trend of the CVL.

Volcanic flows generally cover areas where eruptions occur, which bury structural features like faults making it difficult for geological surveys to be carried out. However, geophysical studies enable to highlight structural 
features and understand the subsurface structure in such areas. For example, Noutchogwe (2010) presented a close correlation between the lineaments inferred from magnetic anomalies, the sites of thermo-mineral springs and the hydrographical network in Adamawa Cameroon. Using gravity data, Jaffal et al. (2010), Fan et al. (2014) and Abate Essi et al. (2017) showed the importance of geophysical lineaments in studying ore bodies and mineralized areas. Therefore, geophysical investigation is helpful to delineate outcropped or buried faults. The aim of this paper is to use gravity data derived from the Earth Gravitational Model EGM2008 to investigate the subsurface of the CVL with an emphasis on structural features.

\section{Geological and structural setting}

The study area comprises the main domain of the continental part of the Cameroon Volcanic Line (CVL). This volcanic line, which crosscuts the Pan-African Fold Belt, is also surrounded at its southern-eastern edge by the Congo craton (Fig. 1). The CVL is a $1600-\mathrm{km}$-long alignment of Cenozoic to recent volcanic massifs and plutons striking N30E (Le Maréchal 1976; Déruelle et al. 1991, 2007). The oceanic section of the CVL lies within the Gulf of Guinea consisting of the islands of Pagalu, São Tomé, Principe, and Bioko, while the continental part is made of two main plateaus (Biu and Ngaoundéré) and several volcanic mountains. Main mountains are mount (Mt) Cameroon $(4095 \mathrm{~m})$ which is the highest and the most active volcanoes of the CVL, mainly formed by alkaline basalts (Hedberg 1968; Déruelle et al. 2007); Mt Manengouba $(2420 \mathrm{~m})$ characterized by basaltic, trachytic and rhyolitic formations; Mt Bambouto (2679 m) with alkaline basalts and trachytes, and Mt Oku (3011 m) consisting of transitional basalt, quartz trachyte and rhyolite flows (Tchoua 1974; Fitton and Dunlop 1985).

The continental structure of the CVL is marked by an alternation of horsts and grabens (Nkouathio et al. 2008). The horsts are made of large polygenetic volcanoes or volcanic plateaus, characterized by complete magmas series, whereas the grabens are monogenetic volcanic fields displaying basic magmas suites (basanites, basalts, and accessory hawaiites) (Tamen et al. 2007). Van Houten (1983) and Ngounouno et al. (2000) interpreted the CVL as a volcanic and subvolcanic alignment resulting from hotspot activity. Fitton $(1980,1983)$ presented it as an active rift system produced by a thermal anomaly in the asthenosphere. Some authors like Déruelle et al. (1991), Moreau et al. (1987) and Nkono et al. (2014) described it as the consequence of the rejuvenation of a Pan-African $\mathrm{N} 70^{\circ} \mathrm{E}$ fracture zone which took place at the opening of the Atlantic Ocean.

The Pan-African Fold Belt of the study area (Fig. 2) includes pre, syn to late tectonic granitoids mainly calk-alkaline composition aged between 660 and $580 \mathrm{Ma}$ (Toteu et al. 1987, 2004) and Neoproterozoic medium- to high-grade schists and gneisses (Koch 1953; Champetier de Ribes and Aubague 1956; Weecksteen 1957; Champetier de Ribes and Reyre 1959; Dumort 1968; Peronne 1969; Ngako 1986; Toteu et al. 2001). These Precambrian Pan-African metamorphic and plutonic formations are overlaid by a younger sedimentary cover especially at the coastal area and around Mamfe locality (cross river) which belong to the southern part of Benue Trough. The sedimentary formations are dated Cretaceous to actual (Champetier de Ribes and Reyre 1959; Popoff 1987). PanAfrican Fold Belt overthrusts the northern boundary of the Congo craton composed of greenstone belt, TTG (tonalite-trondhjemite-granodiorite) aged Archean to Paleoproterozoic (Maurizot et al. 1986; Pouclet et al. 2007; Van Schmus et al. 2008; Tchameni et al. 2010).

The principal structure of the study area is the Cameroon Volcanic Line characterized by the main direction N30 . Moreau et al. (1987) represented the CVL with a set of transverse parallel fractures which are buried under volcanic lavas trending $\mathrm{N} 20^{\circ}$ to $\mathrm{N} 40^{\circ}$. Volcanic formations are lined up toward NE-SW to NNE-SSW direction (Fig. 3). Moreover, at the Adamawa plateau (Fig. 1),

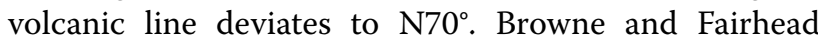
(1983), Koch (1953) and Njonfang et al. (2008) called this brittle tectonic Central African (CASZ), or Adamawa (ASZ), or Foumban shear zone (FSZ). This major shear zone is part of the Central Cameroon shear zone (CCSZ) which extends from the Sudan region to the NE Brazil (Browne and Fairhead 1983; Van Schmus et al. 2008). Nkono et al. (2014) used Shuttle Radar Topography Mission (SRTM), Landsat satellite images and Digital Elevation Models (DEMs) to study the geodynamic setting of the CVL. They inferred two major geodynamic models: a sinistral trans-tensional strain regime on the $\mathrm{N} 70^{\circ}$ fault and a sinistral trans-tensional stress field on the $\mathrm{N} 130^{\circ}$ fault.

Another major shear zone is identified near Ngambe and Edea localities called the Rocher du Loup shear zone (RLSZ) by Ngako et al. (2008) or SW Cameroon Shear zone (SWCSZ) by Nsifa et al. (2013). It is described as a sinistral transcurrent deformation along the western border of the Congo craton.

\section{Data and methodology \\ Data}

In this work, we used gravity data from the geopotential field model EGM2008 released by National Geospatial Intelligence Agency (NGA), which is an improved version of the Earth Gravitational Model EGM96. EGM2008 combines marine, airborne, satellite-altimetry-derived and terrestrial gravity data (Collignon 1968; 


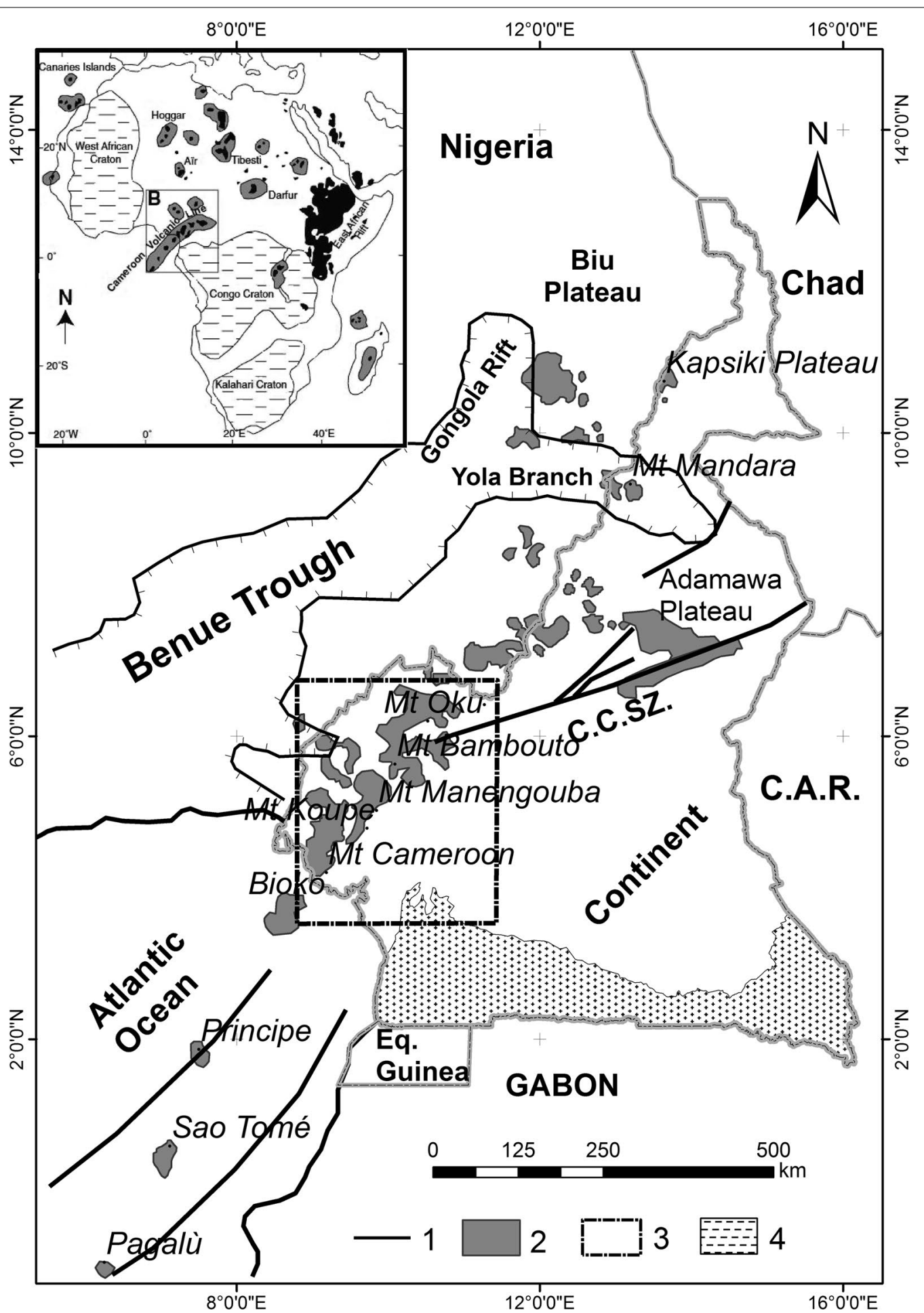

Fig. 1 Location of the Cameroon Volcanic Line. C.A.R. Central African Republic, Eq. Equatorial, CCSZ Central Cameroon shear zone, 1 fault, 2 Cameroon Volcanic Line, 3 Pan-African fold belt, 4 Congo craton (modified from Lee et al. 1994; Ballentine et al. 1997; Ngako et al. 2006; Nkouathio et al. 2008) 


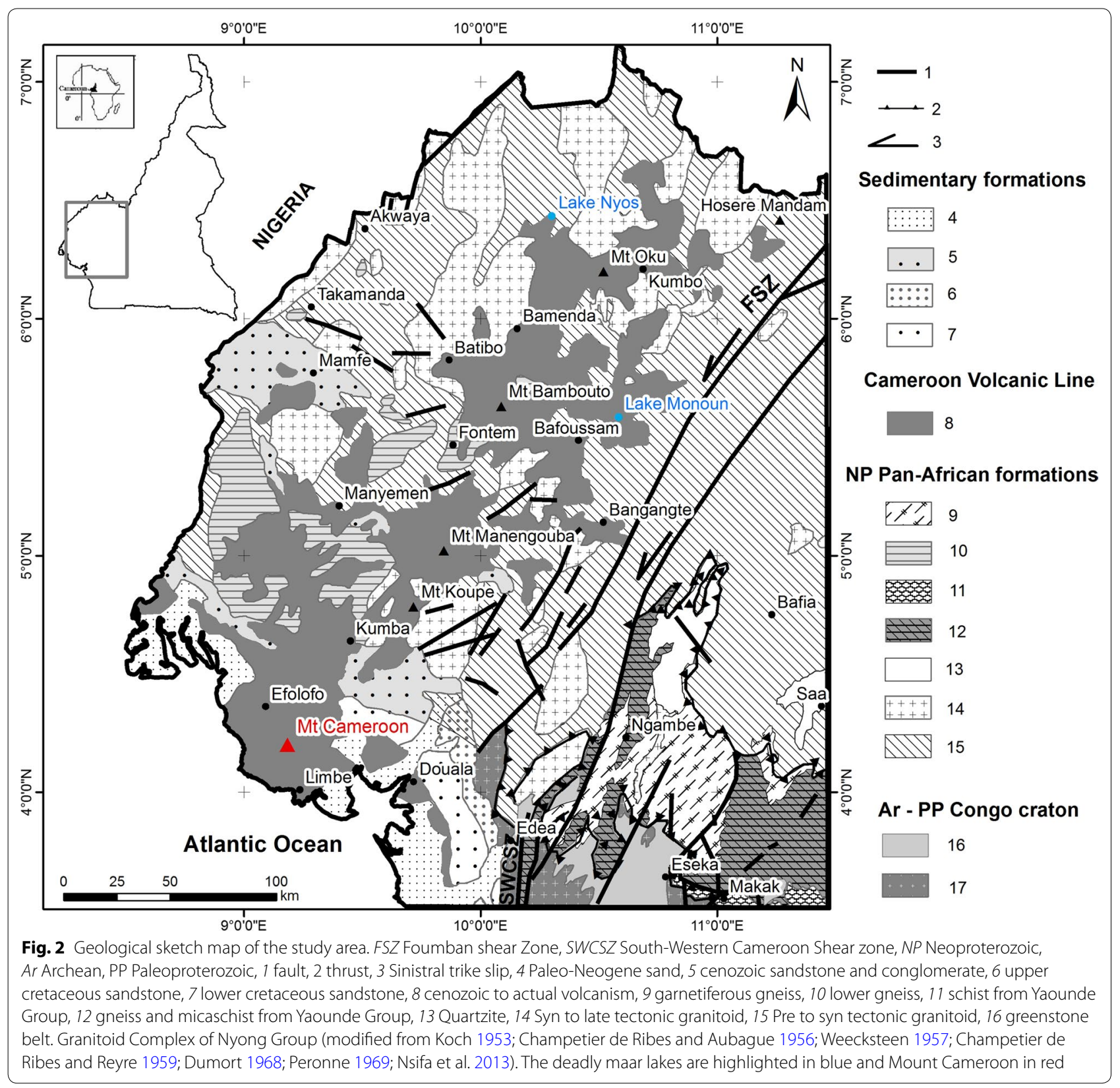

Poudjom-Djomani 1993; Poudjom-Djomani et al. 1996) to model the global gravity field with a spatial resolution of 5 by 5 arc minutes. It is complete to spherical harmonic degree and order 2159 and contains additional coefficients extending to degree 2190 and order 2159 (Pavlis et al. 2012). The spherical harmonic coefficients of the EGM2008 are used to derive a geoid referenced to WGS 1984 and to calculate free air anomalies (Eyike et al. 2010). Assuming a density of $2.67 \mathrm{~g} \mathrm{~cm}^{-3}$ for Bouguer slab, we applied topographic correction to free air anomalies using the digital elevation model Etopo 1 (Amante and Eakins 2008) to obtain Bouguer anomalies.

This high spatial resolution model provides a widespread information and covers areas previously lacking terrestrial data (Fig. 4). Significant similarities are found by Eyike et al. (2010) and Abate Essi et al. (2017) after comparing terrestrial gravity and EGM2008 data for Cameroon. Likewise, Marcel et al. (2016) investigated the Moho discontinuity depth along the CVL with EGM2008 data and found results in conformity 


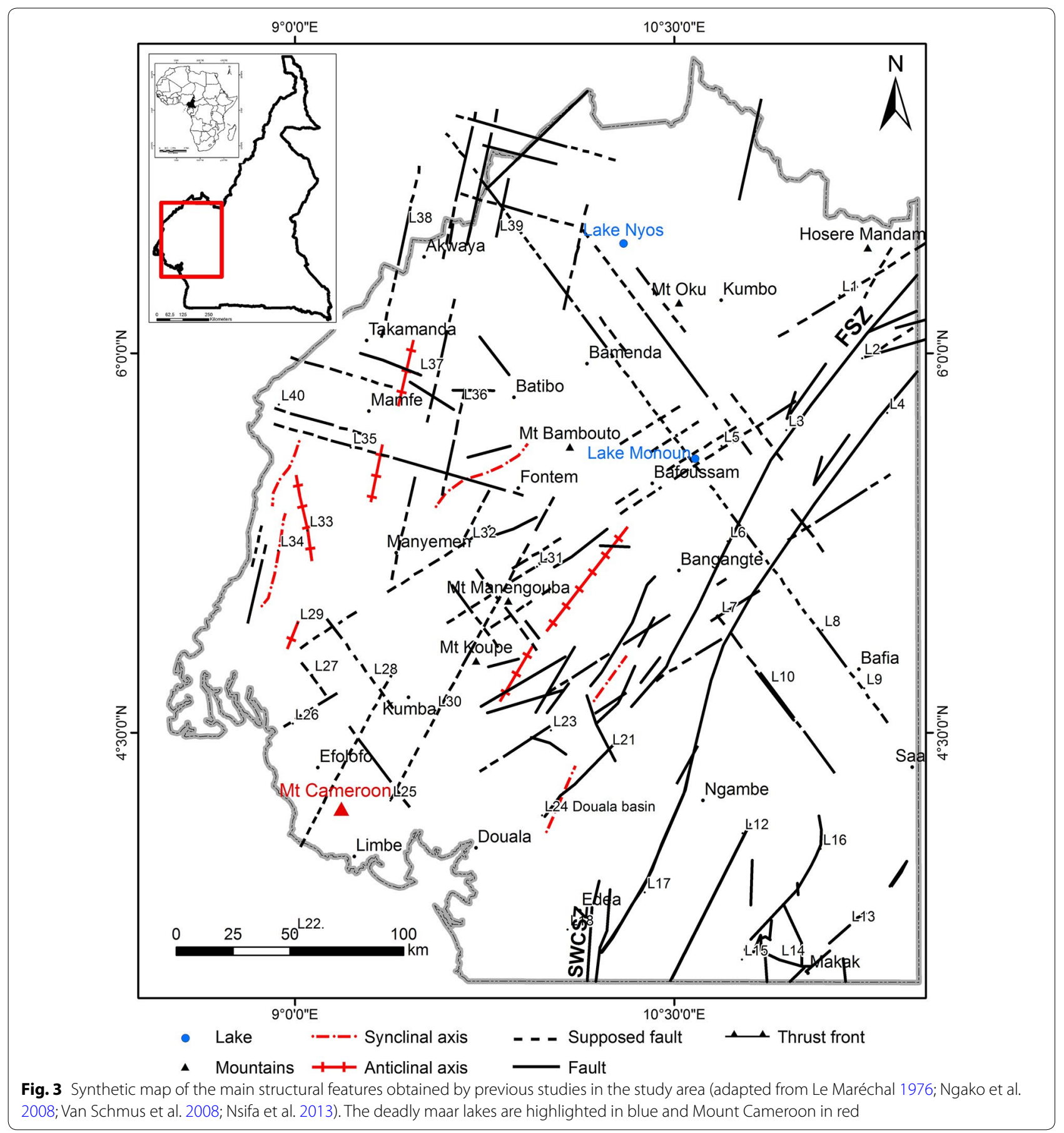

with previous studies which used terrestrial gravity and seismic data. These authors suggested that gravity data derived from EGM2008 can efficiently be used to overcome the absence and the sparseness of terrestrial gravity data. EGM2008 gravity data are therefore suitable for mountainous and volcanic areas where terrestrial gravity surveys cannot easily be covered such as the present study area.

\section{Bouguer anomalies}

The EGM2008 Bouguer anomaly map of the study area is presented in Fig. 4. The gridding method used to realize the Bouguer anomaly map is minimum curvature with a grid size of $0.01^{\circ}$ (about $1.1 \mathrm{~km}$ ). Ngatchou et al. (2014) have successfully experimented this grid size while studying the structure of crust beneath Cameroon from EGM2008. Gridding method generates interpolated 


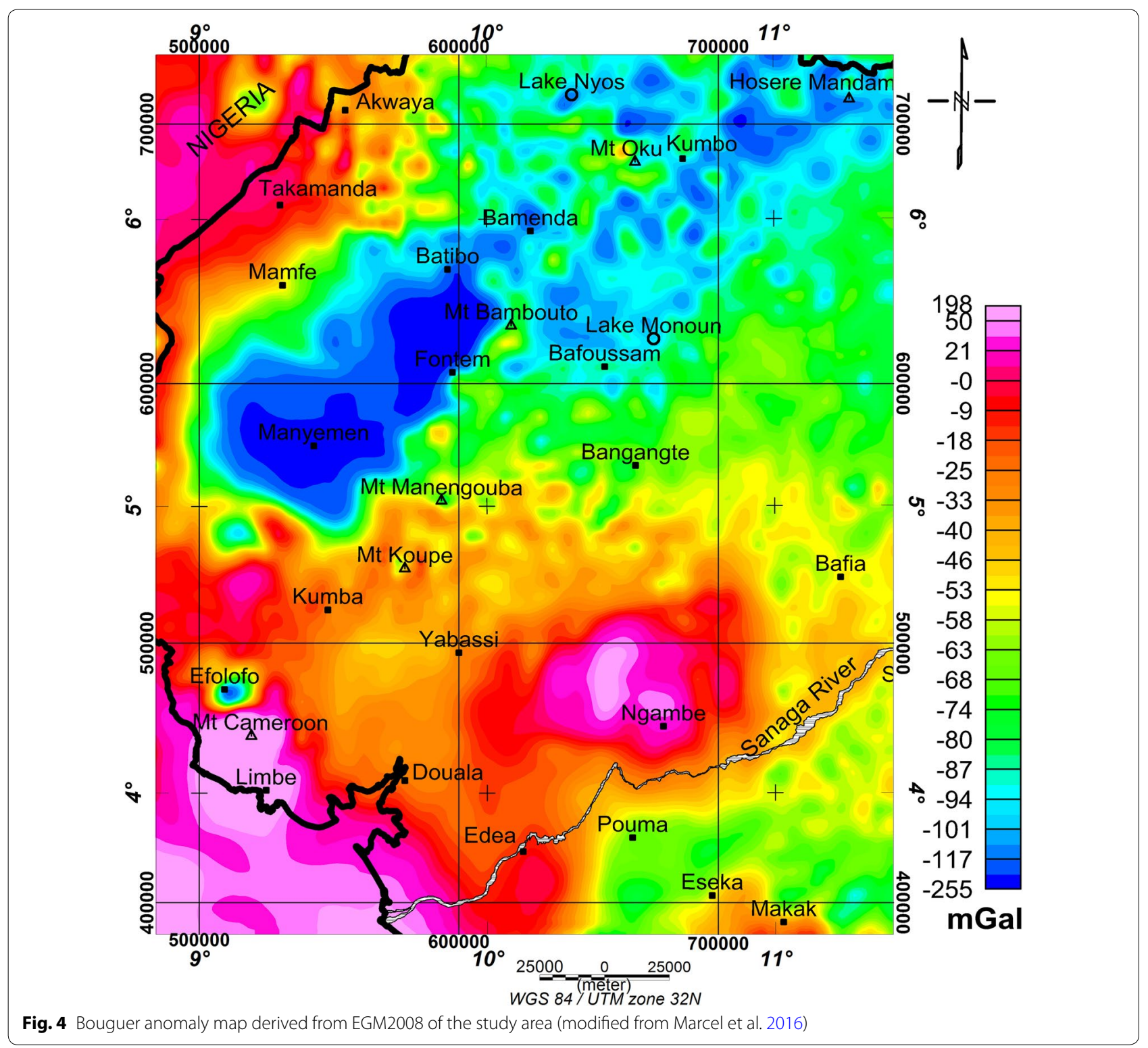

surface analogous to a thin, linearly elastic plate passing through each of the data values with a minimum amount of bending.

Bouguer anomaly values range from -255 to $198 \mathrm{mGal}$. From Manyemen to Hossere Mandam localities, negative anomalies $(-255$ to $-80 \mathrm{mGal})$ appear along a corridor particularly trending NE-SW. The corridor of negative values coincides with the Cameroon Volcanic Line and a part of the sedimentary basin of Mamfe (which belongs to the southern part of Benue Trough). This corridor crosscuts an area marked by a relatively high Bouguer anomaly representing the granite-gneiss basement of Pan-African Fold Belt. The contact zone between Congo craton and Pan-African Fold
Belt in Ngambe area is underlined by a positive anomaly with high amplitude (more than $100 \mathrm{mGal}$ ). The highest positive anomaly (greater than $150 \mathrm{mGal}$ ) is located in the Atlantic Ocean including Limbe and Mount Cameroon areas. From the analysis, it is possible to perform a correlation between the geological (Fig. 2) and Bouguer anomaly maps (Fig. 4).

\section{Residual anomalies}

Bouguer anomalies involve gravity signature due to the influence of both shallow and deep structures in the terrestrial subsurface. Therefore, in order to study the subsurface features, residual anomalies will be described since they provide the heterogeneity of geological 
formations, characterized by density variations inside the terrestrial crust (Abate Essi et al. 2017). The residual anomaly map (Fig. 5) presents values ranging from -157 to $186 \mathrm{mGal}$ mainly grouped in positive $(\mathrm{P})$ and negative (N) anomalies summarized in Table 1.

Negative anomalies are nominally distinguished as N1, N2, N3 and N4. These zones referred as sedimentary basins (Fig. 5) or swamp zones, suggesting low-density materials. N1 anomaly brings out Douala sedimentary basin described as a Lower Cretaceous basin (Regnoult 1986; Nguene et al. 1992). Along Eseka and Bafia localities, negative anomalies named N2 expose low-density geological formations. This specific zone is intensely drained by Sanaga River and its tributaries, indicating that it is made of alluvias; thus, less geological outcrops are found. Both anomalies N3 and N4 represent the southern part of Benue Trough filled by cretaceous sedimentary deposits (Benkhelil 1986) of low density.

EGM2008 residual anomaly map reveals a positive anomaly (P5) with values higher than $100 \mathrm{mGal}$. In this area, the geological map (Fig. 2) exposes some granitoid intrusions. Mount Cameroon is located on a positive anomaly (P1). Similarly, successive located positive anomalies (P4) are appreciable in this volcanic area with the same orientation NE-SW of the CVL. Ngambe zone presents a circular positive anomaly around the contact between Congo craton and Pan-African Fold Belt corresponding to a particular garnet gneiss in the previous

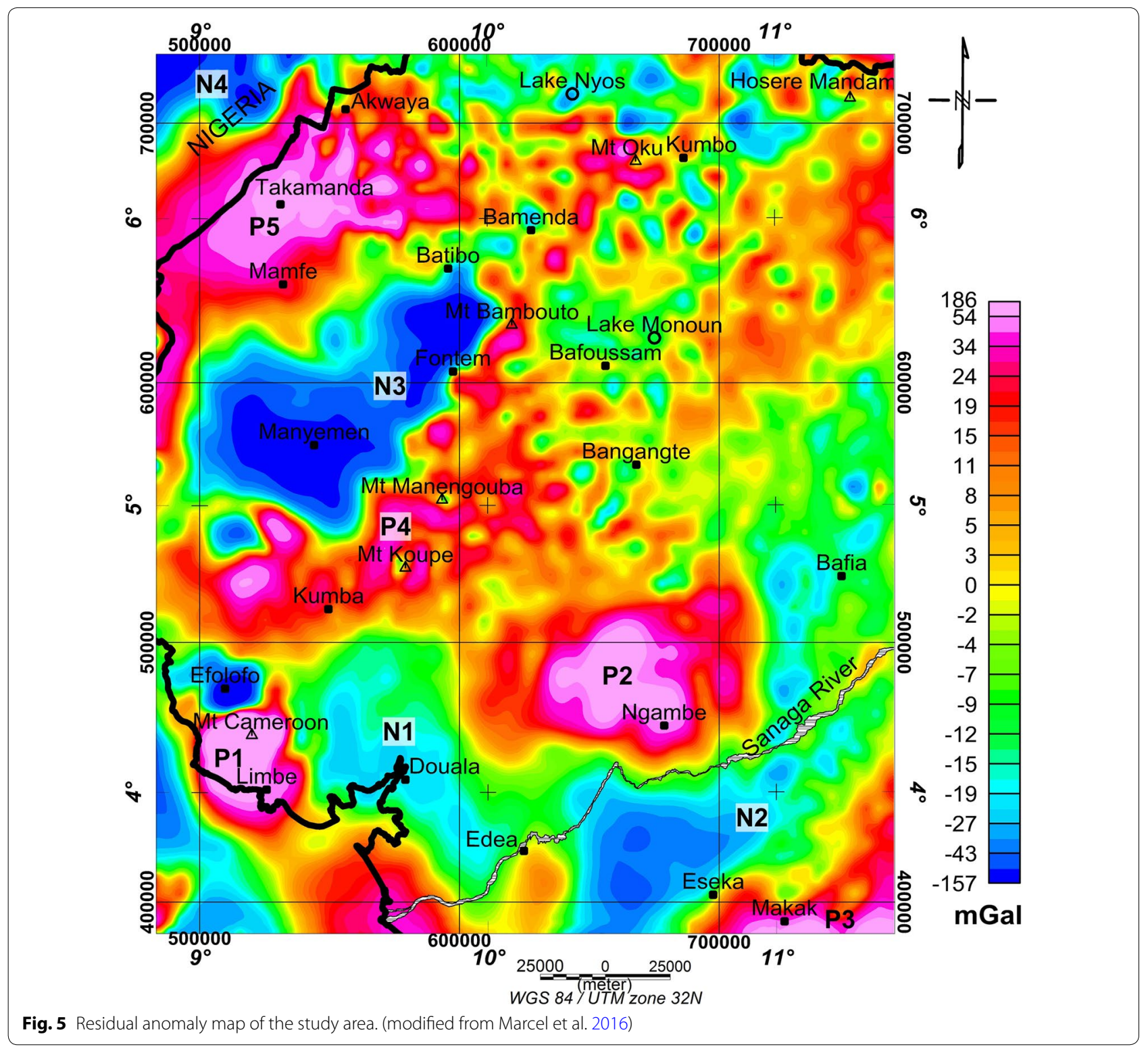


Table 1 Main gravity anomalies of residual map

\begin{tabular}{llll}
\hline Anomaly & Direction/shape & Location & Significance \\
\hline N1 & NW-SE & Douala & Douala Sedimentary basin \\
N2 & N-S & Eseka-Bafia & Swamp and sedimentary alluvia (Sanaga River) \\
N3 & NE-SW & Manyamen-Fontem & Mamfe basin (southern part of Benue Trough) \\
N4 & Circular & North of Takamenda (Nigeria) & Benue Trough \\
P1 & Circular & Mt Cameroon & Volcanic mountain of the CVL \\
P2 & Circular & Ngambe & Granitoid intrusion \\
P3 & NE-SW & East of Makak locality & Iron mineralization located at the northern edge of Congo craton \\
P4 & Successive circular trending NE-SW & Kumba-Mt Oku & Volcanic mountains of the CVL \\
P5 & E-W & Takamanda & Granitoid intrusion \\
\hline
\end{tabular}

geological map. Positive anomaly (P3) may display iron mineralization described by Ngoumou et al. (2014) around the locality of Eseka at the northern edge of Congo craton.

\section{Methodology}

Bouguer anomaly map obtained from the geopotential field data is filtered. The methodology used in this work involves a combination of techniques comprising upward continuation, horizontal gradient, maxima of horizontal gradient coupled to upward continuation technique and Euler deconvolution. This combination of techniques has the particularity in studying gravity signatures of subsurface geological features. The grid size of Bouguer anomaly map $\left(0.01^{\circ}\right)$ is maintained during the filtering.

\section{Upward continuation}

The Bouguer anomaly map is smoothed with upward continuation technique. This operation consists of the application of a low passed filter that attenuates short wavelengths while amplifying long wavelengths (Jacobsen 1987). The Jacobsen's theory suggests that the field resulting from upward continuation to a level of $Z$ focuses on sources situated at a minimum depth of $Z_{0}=1 / 2 Z$. Thus, this method is suitable to study deeper and major crustal structure of the regions of interest.

\section{Horizontal gradient}

Horizontal gradient is an efficient technique to delineate subsurface geological features. It highlights lineaments like fractures, faults and geological contacts characterized by local maxima of gravity field (Grauch and Cordell 1987; Philips 1998). The advantage of horizontal gradient method is its stability in the presence of noise in potential field data (Phillips 1998). Considering a gravity field $G$ ( $x$, $y$ ), the horizontal gradient magnitude HG is given by the following expression (Philips 1998):

$$
\mathrm{HG}=\sqrt{\left(\frac{\partial G}{\partial x}\right)^{2}+\left(\frac{\partial G}{\partial y}\right)^{2}}
$$

\section{Maxima of horizontal gradient coupled to upward continuation method}

This method combines the two techniques mentioned above. This combination is used not only to bring out lineaments but also to evaluate different dips (vertical and oblique). It entails applying the upward continuation filter to the Bouguer anomalies at progressive heights and to determine the horizontal gradient of each upward continued distance (Blakely and Simpson 1986; Everaerts and Mansy 2001; Jaffal et al. 2010; Hadhemi et al. 2016). For each upward continued map, we represent essentially the maxima of the horizontal gradient in the map (Blakely and Simpson 1986). A displacement of maxima will correspond to the dip orientation. Thus, a vertical dip will display superimposed maxima of different altitudes.

\section{Euler deconvolution}

Euler deconvolution is a semi-automatic method to estimate the position and the depth of a causative source of magnetic or gravity field (Thompson 1982; Reid et al. 1990). This method relates the gravity field and its gradient components to the location of the source of an anomaly, with the degree of homogeneity expressed as a "structural index." Thompson (1982) proposed the following homogeneity Eq. (2):

$$
\left(x-x_{0}\right) \frac{\partial g}{\partial x}+\left(y-y_{0}\right) \frac{\partial g}{\partial y}+\left(z-z_{0}\right) \frac{\partial g}{\partial z}=-\mathrm{NG}
$$

where $\left(x_{0}, y_{0}, z_{0}\right)$ are the coordinates of the source whose gravity field $(g)$ is detected at $(x, y, z), N$ is the structural index interpreted as the measure of the fall-off rate of the gravity field with distance from the source. This last parameter $(N)$ determines the dimension of 
a given source to bring out a specific study. For gravity data, structural index ranges from 0 to 2 . However, $N=0$ implies that the gravity field is constant regardless of distance from the source model. These solutions are physically impossible for real data (Thompson 1982). Deconvolution of Euler is an adequate technique to delineate geological contact or fault with a structural index ranging between 0 and 1 , but mostly near the value 0 .

\section{Results}

\section{Upward continuation for regional structure}

Bouguer anomalies are submitted to upward continuation filtering at $5,10,20$ and $40 \mathrm{~km}$. This operation accentuates the effect of deep gravity sources and attenuates or even removes the influence of the superficial ones (Jacobsen 1987; Marcel et al. 2016; Abate Essi et al. 2017). Hence, this low passed filter transforms and smooths gradually the initial uneven Bouguer anomalies (Fig. 4) into smoothed anomalies highlighting regional crustal features. In Fig. 6, anomaly values range from -241 to $180 \mathrm{mGal}$ (Fig. 6a) at $5 \mathrm{~km}$ upward continued distance, afterward -135 to $80 \mathrm{mGal}$ at $10 \mathrm{~km}$ upward continued distance (Fig. 6b), then vary between -104 and $61 \mathrm{mGal}$ at $20 \mathrm{~km}$ upward continued distance (Fig. 6c) and finally extend from - 105 to 46 mGal (Fig. 6d). Superficial and individual anomalies are unified proportionately with the upward continuation distance. Regional structure of the study area is very well exposed on negative anomalies around Manyemen till Hossere Mandam localities (Fig. 6c, d). This regional structure trends approximatively NNE-SSW direction corresponding to the CVL orientation. In a similar manner, the oceanic part of the CVL, carrying Mount Cameroon, in the upward continuation maps presents a protuberance at Ngambe locality running parallel to the major orientation.

\section{Horizontal gradient}

Horizontal gradient is performed in Fig. 7. It is assumed that the maxima of magnitude (Blakely and Simpson 1986) is located where steep density contrasts. Horizontal gradient peaks are therefore interpreted as geological structures such as geological contacts or faults (Jaffal et al. 2010; Hadhemi et al. 2016). The geometry of horizontal gradient peaks is very characteristic of the highlighted element. Furthermore, an elongated and more or less rectilinear peak can easily tally with a fault, whereas a curved or circular peak contour will refer to geological contact of an igneous intrusion, dome or diapir.

Figure 7 presents the horizontal gradient of the study area obtained from the Bouguer anomalies of the study area (Fig. 4). Mount Cameroon and Ngambe localities expose heavy-density materials. Referring to geological map (Fig. 3), Mount Cameroon is made of extrusive volcanic deposits, while Ngambe area carries garnetiferous metamorphic formations. The eastern part of Sanaga River presents water flow related to a NE-SW fault.

Several horizontal gradient maxima (some are curvilinear and others are linear) are located along the Cameroon Volcanic Line. This result demonstrates that the CVL is a fractured zone and consists of mountains represented by circular signature. Moreover, Benue Trough coming from Nigeria is evidently revealed around Mamfe and Takamanda zones. Boundary of Manyemen gneiss is revealed in Fig. 2 although partially covered at the surface by volcanic flows of the CVL. Along the western part of Douala and Edea localities, we identify the limits of the Douala sedimentary basin.

\section{Maxima of horizontal gradient coupled with upward continuation}

Figure 8 shows the results of the combination of upward continuation and horizontal gradient technique. In this map, a progressive and regular distance of upward continuation is defined at every $1 \mathrm{~km}$ and the maximum upward height is $10 \mathrm{~km}$. Maxima of horizontal gradient for each prolonged distance have a unique color.

A general overview of this map helps to assert that the littoral zone of the study area (SW of Edea, SW of Douala, SW of Mount Cameroon) shows lineaments dipping W to SW. The sedimentary areas highlight very few lineaments especially in Douala basin and Benue Trough (North of Efolofo and Mamfe areas). Concerning the CVL area, we note abundant fractures with both inclined and vertical dips. Deadly lakes (Nyos and Monoun) are located on this fractured area. The zone carrying Lake Nyos is characterized by the deepest maxima down to $10 \mathrm{~km}$.

\section{Euler deconvolution}

The Euler deconvolution based on homogeneity equation (Thompson 1982; Keating 1998) is another tool used to delineate structures. This technique gives the geographic positions and the depth of gravity sources. We performed a window cell of $15 \times 15 \mathrm{~km}$ to solve the equation with a structural index of 0.1 . This structural index is chosen near zero because it helps to highlight subsurface contacts or faults. Figure 9 illustrates the results of Euler's solutions of the study area. The depth ranges between $1 \mathrm{~km}$ to $10 \mathrm{~km}$, with a mean value of $4227 \mathrm{~m}$ and standard deviation of $2288 \mathrm{~m}$. Sources of gravity field are not equally distributed in the map although some interesting lineaments can be observed. Littoral zone (the western part of Douala and Edea localities) presents a deep lineament trending NW-SE corresponding to the limit of the Douala sedimentary basin. Likewise, Sanaga River flows on fractured zones, deeper in the delta than in the inner continent. Fractures of the CVL distinguish themselves 


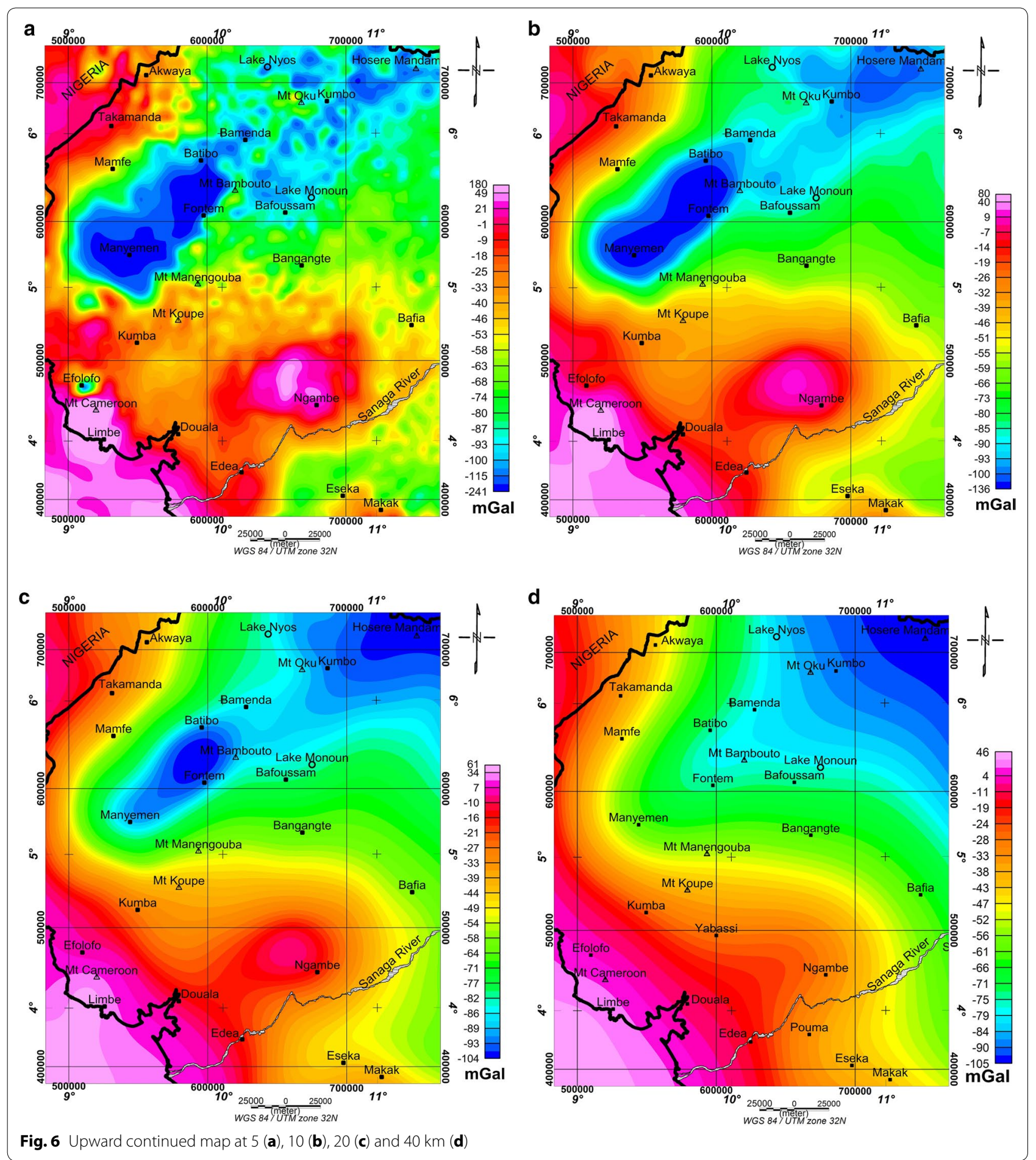




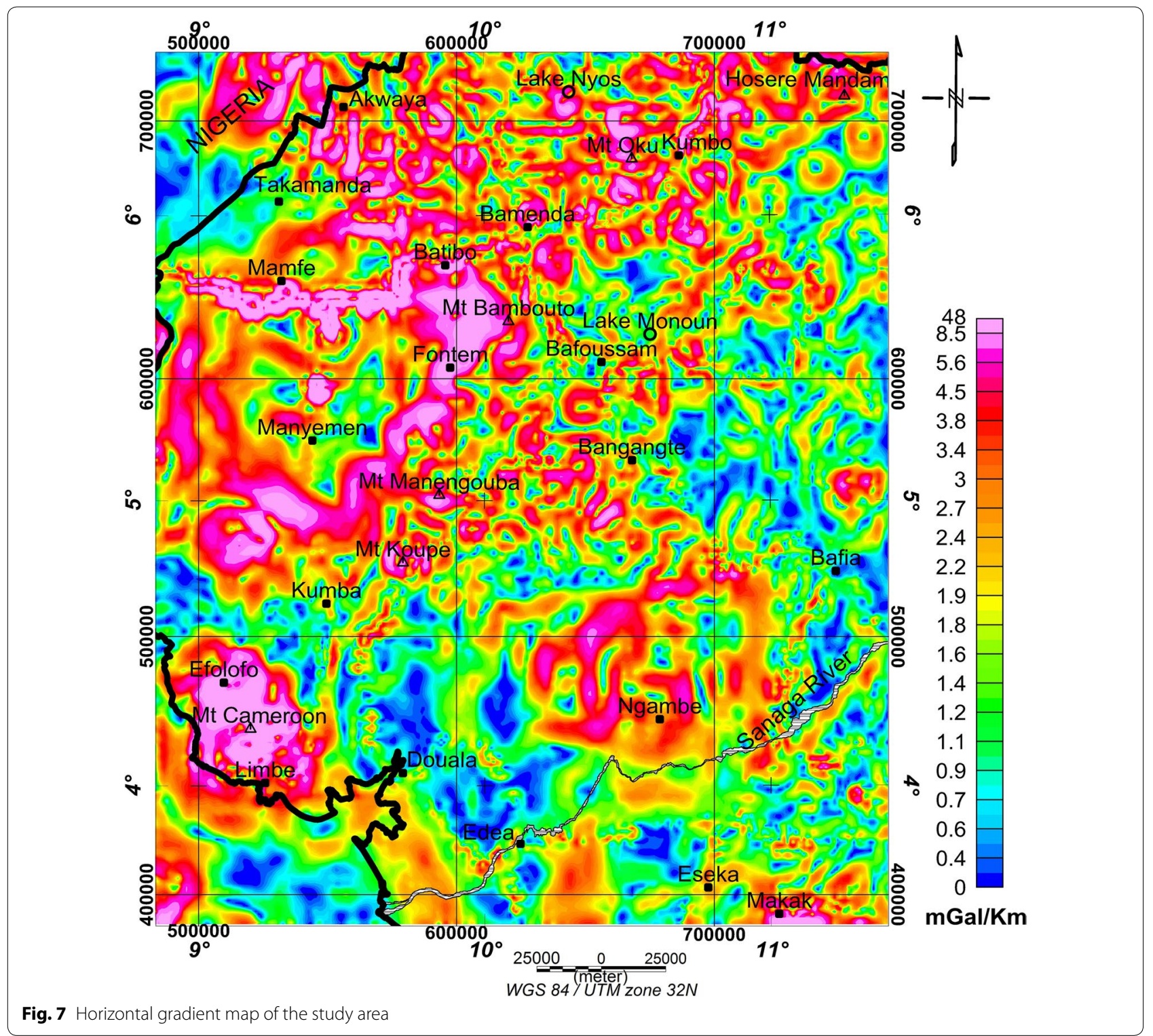

in Limbe, Mount Cameroon, Fontem and Mount Bamboutos localities. On the western side of the CVL, deed fractures trending $\mathrm{N}-\mathrm{S}$ and covered by Benue Trough sediments are highlighted.

\section{Discussion}

\section{Validation of results}

This work was carried out in an area where volcanic activities are still active (materialized by gas emissions in lakes Nyos and Monoun, and eruptions in Mount Cameroon). Based on the identification of known geological features, the main findings demonstrate the reliability of the gravity data derived from the Earth Gravitational Model EGM2008. Ground gravity data are usual tools to study the subsurface of terrestrial crust (Poudjom-Djomani 1993; Marcel et al. 2010; Jaffal et al. 2010; Hadhemi et al. 2016). The study area comprises volcanic mountains which are hardly surveyed by ground gravity campaigns. It presents therefore an actual challenge for a continuous spatial investigation. The Earth gravitational Model EGM2008 which integrates terrestrial and satellite gravity data enables to overcome the sparseness in gravity maps due to lack of data.

Upward continued maps highlighted a NE-SW trending regional structure which corresponds to the CVL direction (Le Maréchal 1976). Besides, subsurface formations of previous geological studies are well expressed through residual anomaly map. Gravity data derived from 


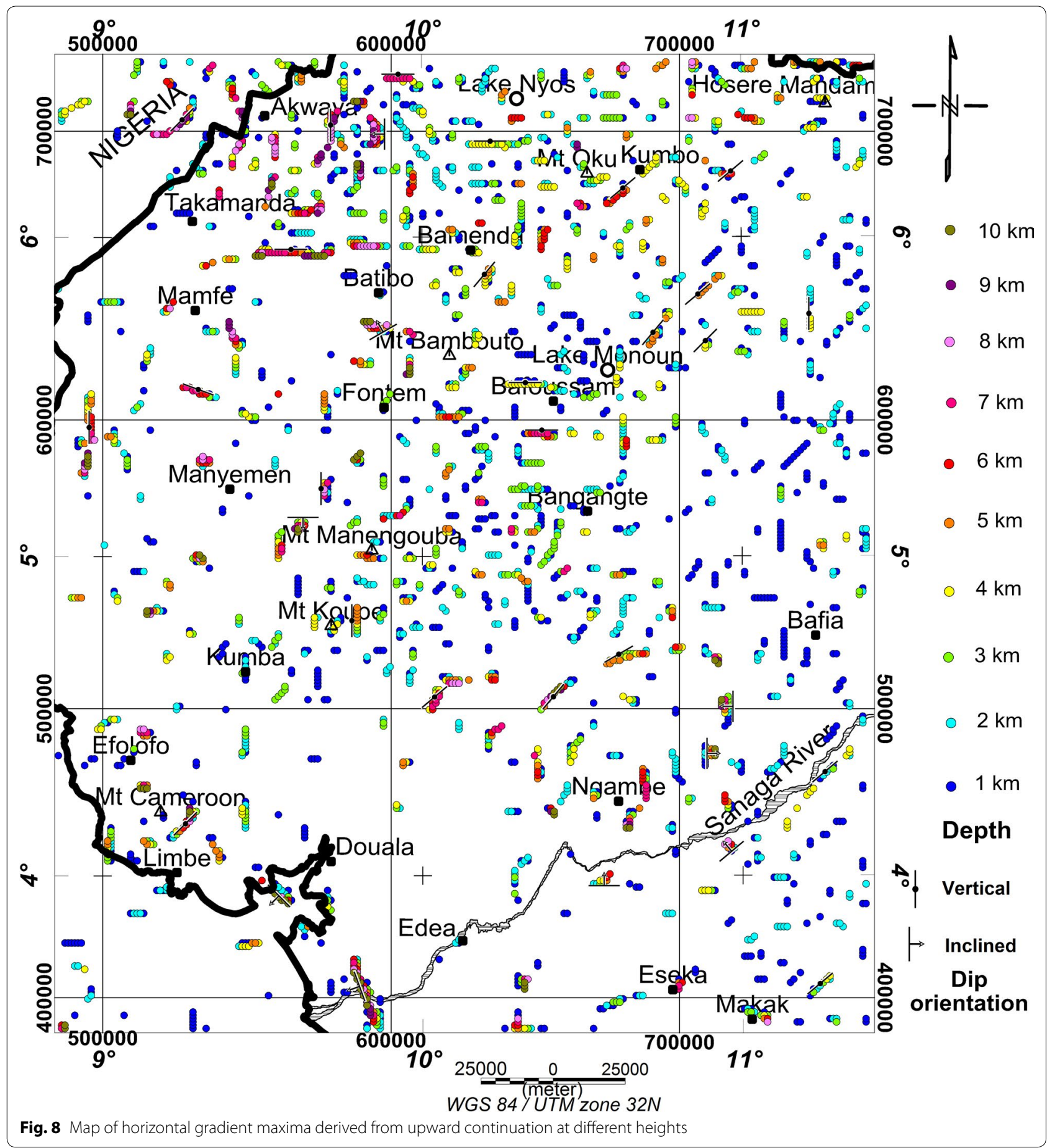






EGM2008 expose efficiently the geophysical response of the geology in the area of study. Located dense materials of volcanic formations like basalts (Telford et al. 1990) are aligned in the same direction with the CVL $\left(\mathrm{N} 30^{\circ}\right)$.
This residual anomaly map presents obviously sedimentary basin characterized by low amplitude anomaly such as Douala basin filled by cretaceous deposits (Regnoult 1986; Nguene et al. 1992) and the cretaceous Benue 
Trough. Positive residual anomaly of Ngambe exposes the garnetiferous gneiss. Abate Essi (2010) studied the density of diverse geological formations of Pan-African Fold Belt and showed that garnetiferous gneiss of Yaoundé Group and especially where there is intense accumulation of garnet called garnetite or garnet rock has high density above $3 \mathrm{~g} / \mathrm{cm}^{3}$. EGM2008 is therefore useful for geological investigation based on rock density variation. Furthermore, horizontal gradient maxima derived from upward continuation at different heights and deconvolution of Euler enable to characterize some structural linear features. These two last techniques present approximately similar limit depth of features at $10 \mathrm{~km}$. The lineaments highlighted in this work are discussed in the next section.

\section{Structural contribution}

Previous works on the CVL put in evidence lineaments (Fig. 2) like faults using geological surveys (Ngako et al. 2006; Nkouathio et al. 2008; Nsifa et al. 2013) and remote sensing interpretation (Moreau et al. 1986; Nkono et al. 2014). The CVL is made of Cenozoic to recent volcanic lavas that assuredly buried fractures. Geopotential field data especially gravity data derived from EGM2008 (Pavlis et al. 2012) in our case enable to delineate some shallow structures based on density variations of geological bodies within the crust. Figure 10 presents lineaments deduced from the combination of different techniques used in this work (horizontal gradient, horizontal gradient maxima coupled with the upward continuation, Euler deconvolution). This map brings out well-known lineaments and reveals new ones. The confirmation of known lineaments demonstrates the efficiency of the geopotential model EGM2008 to highlight subsurface linear features interpreted as faults or geological contacts. Consequently, regional structural analysis in mountainous zones can be performed with the help of gravity data derived from EGM2008. Hence, a synoptic table (Table 2) summarizes interesting lineaments in accordance with previous works.

Lineaments L2 and L3 follow an ENE-WSW and NE-SW directions, respectively. They tally the Foumban shear zone representing the ending of Central Africa shear zone CASZ (Ngako et al. 1991, Njonfang et al. 2008). Sanaga River is delineated by lineaments L11- and L16-oriented NE-SW. Lineament L18 trending $\mathrm{N}-\mathrm{S}$ superimposes the South-Western Cameroon shear zone (SWCSZ) and corresponds to a deep fault (Euler deconvolution displayed approximatively $8 \mathrm{~km}$ of depth). Besides, another deep fracture trending NW-SE is detected at the contact ocean-continent (lineament L20); therein, the maxima of horizontal gradient coupled with upward continuation method reveal its westward dip. At the east side of L20, the contact between sedimentary basin of Douala and Pan-African Fold Belt is put in evidence under L24. L22 is oriented NE-SW and represents a lineament crossing the Bioko volcanic island. The northern edge of Congo craton in contact with PanAfrican Fold Belt describes a thrust front (Ngako et al. 2008; Toteu et al. 2001) whither L15, L17, L19 are highlighted with a NE-SW orientation. In the Pan-African Fold Belt around Hosere Mandam, the geological contact between granite and high-grade gneiss, put in evidence by Koch (1953), is confirmed in this study with lineament L1 trending NE-SW. In addition, NE-SW Benekuma fault, N-S Mundemba anticlinal, Bikoki anticlinal as well as anticlinal in Takamanda granite are identified in this work by L39, L34, L33 and L37, respectively. Sedimentary basin of Mamfe, the southern part of Benue Trough, underlines lineament L40.

The statistical analysis is performed in the rose diagram (Fig. 11). This diagram includes confirmed and revealed lineaments. It translates widely the CVL direction as the major tectonic feature of the study area trending NE-SW.

The new lineaments revealed in this study added to the previous ones show that the study area is very fractured. The findings of this study provide an opportunity for more research on the CVL. Some of the previous lineaments (Fig. 3) have not been highlighted in this study. This may be due to the resolution of EGM2008 (5 arcminutes) which may not be suitable to locate and detect more detailed information of the subsurface. Other techniques such as seismic, aeromagnetic investigations, satellite imagery, ground geological verification, etc. can be integrated for more efficient results. However, this statistical result of lineaments (Fig. 11) confirms the reliability of EGM2008.

\section{Geohazard and land-use: development planning implications}

Numerous lineaments are highlighted in this continental part of the CVL. Many of them confirm earlier studies while other ones are revealed. They generally refer to faults or geological contacts as described above. These lineaments express locally weakness zones of the subsurface in the terrestrial crust. Tamen et al. (2007) suggest that lineaments in the basement rocks work as pathways for magma ascent. In the study area, two different types of volcanic activities still occur: volcanic eruptions in Mount Cameroon (latest eruptions in 2000, 1999, 1982) and the famous deadly gas emissions from maar lakes of Monoun (in 1984) and Nyos (in 1986). It is also important to point here that several other maars are numbered in this volcanic sector. Maar defines shallow volcanic craters with steep sides. Some of the CVL maars have been studied: Nyos (Lockwood and Rubin 1989), Barombi 


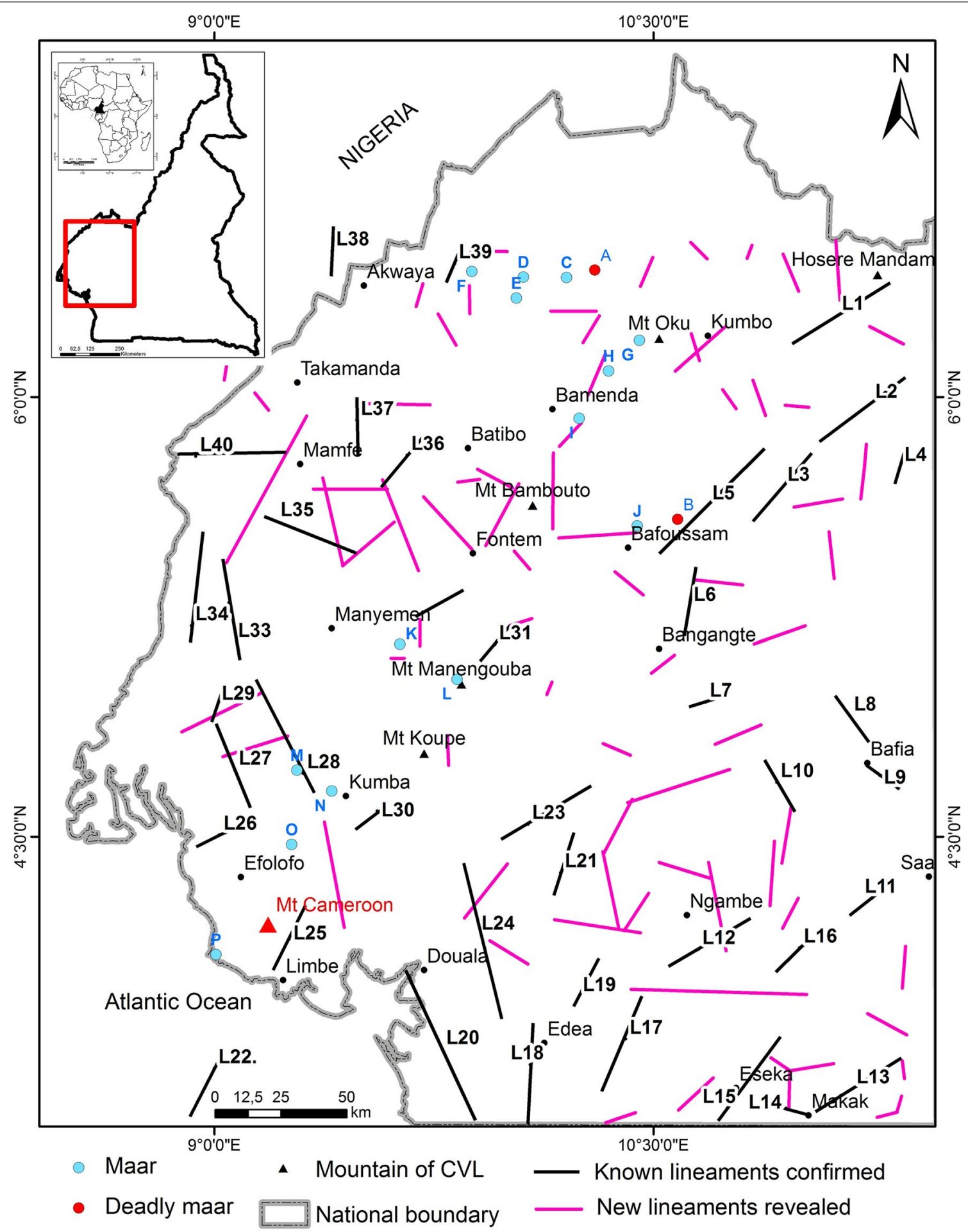

Fig. 10 Lineaments extracted from gravity data derived from EGM2008. Maars of study area (A Nyos maars, B Monoun, C Mbulom, D Wum maar, $E$ Mbellifang maar, F Benakuma, G Oku maar, H Sabga maar, I Bambili maar, J Baleng, K Beme, L Manengouba maar, M Bikoki maar, N Barombi maar, $O$ Barombi Koto maar, $P$ Debunscha) The deadly maar lakes and Mount Cameroon are highlighted in red 
Table 2 Summary of main lineaments identified in the study area

\begin{tabular}{|c|c|c|}
\hline Lineaments & Trend & Significance \\
\hline L20 & NW-SE & Boundary fault continent-ocean \\
\hline L24 & $\mathrm{N}-\mathrm{S}$ & $\begin{array}{l}\text { Limit Douala sedimentary basin_-Pan- } \\
\text { African belt }\end{array}$ \\
\hline L15, L17, L19 & NE-SW & Contact Pan-African Belt_-Congo craton \\
\hline L11, L16 & NE-SW & Sanaga River fault \\
\hline L18 & $\mathrm{N}-\mathrm{S}$ & SW Cameroon SZ \\
\hline L22 & NE-SW & Lineament of Bioko island \\
\hline L34 & $\mathrm{N}-\mathrm{S}$ & Mundemba synclinal \\
\hline L33 & $\mathrm{N}-\mathrm{S}$ & Bikoki Anticlinal \\
\hline$\llcorner 40$ & $E-W$ & Mamfé lineament \\
\hline L37 & $\mathrm{N}-\mathrm{S}$ & Granit anticlinal of SE Takamanda \\
\hline L39 & NE-SW & Benekuma fault \\
\hline L1 & NE-SW & $\begin{array}{l}\text { Geological contact granite-high-grade } \\
\text { gneiss }\end{array}$ \\
\hline L2, L3 & $\begin{array}{l}\text { ENE-WSW to } \\
\text { NE-SW }\end{array}$ & Foumban SZ (CASZ) \\
\hline
\end{tabular}

Koto (Tamen et al. 2007), Debunschar (Ngwa et al. 2017). The multitude of lineaments puts in evidence in this work attest of the vulnerability of this sector. Thus, special attention should be paid on this zone for geohazard prevention.

\section{Conclusion}

The filtering of gravity data derived from EGM2008 is efficient to explore the Cameroon Volcanic Line. Its NE$\mathrm{SW}$ direction is the main structural feature revealed as confirmed by the rose diagram. In addition, important faults like Foumban (Central Africa) and SW Cameroon shear zones or the contact between Pan-African Fold Belt and Congo craton provide the reliability of this methodological approach. A correspondence is found between gravity anomalies and geological formations. This work corroborates once more the vulnerability of the CVL zone. The distribution of faults and maar lakes shows that special attention should be paid in this sector to prevent

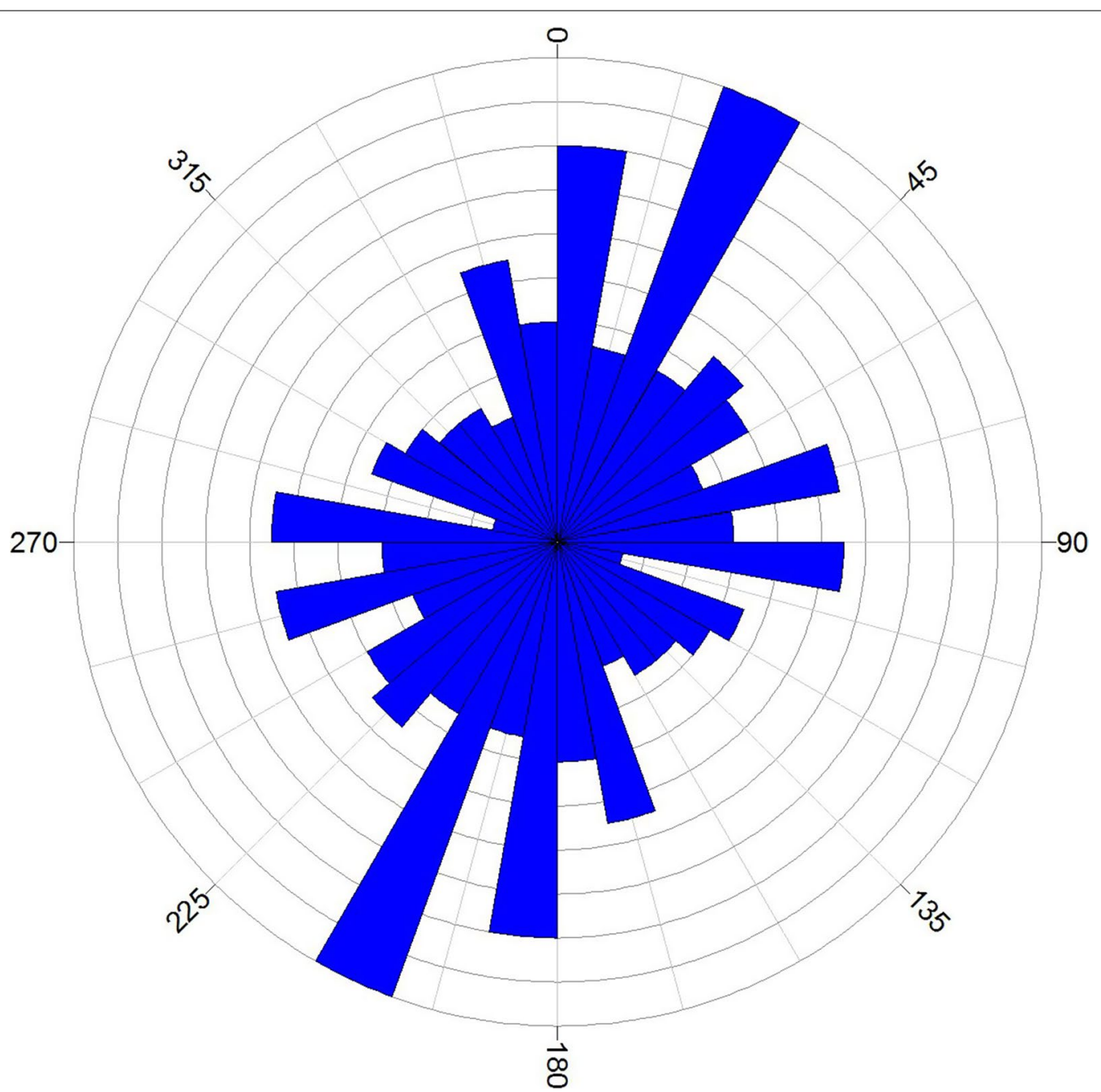

Fig. 11 Rose diagram of lineaments revealed by this work 
natural disasters such as gas emissions of "asleep" maars. The earth gravity model EGM2008 resulting of the combination of terrestrial and altimetry-derived gravity data is therefore advantageous for subsurface investigations in volcanic mountainous areas as the CVL where terrestrial gravity surveys cannot easily reach.

\section{Authors' contributions}

JM conceived of the methodology of data analyses and interpreted geophysical maps. JMAE contributed to the geological aspect of the paper and generated maps. JM and JMAE wrote the first draft of the paper. PN performed critics and improved the interpretation of results. OS participated in designing this study. EM supervised the work and revised the paper. All authors read and approved the final manuscript.

\section{Author details \\ ${ }^{1}$ National Institute of Cartography, P.O. Box 157, Yaoundé, Cameroon. ${ }^{2}$ Insti- tute for Geological and Mining Research, PO Box 333, Garoua, Cameroon. \\ ${ }^{3}$ Department of Physics, Faculty of Science, University of Yaoundé I, Yaoundé, Cameroon. ${ }^{4}$ Department of Earth Science, Faculty of Science, University of Yaoundé I, PO box 812, Yaoundé, Cameroon. ${ }^{5}$ Department of Physics, Faculty of Science, University of Maroua, Maroua, Cameroon.}

\section{Acknowledgements}

The authors are grateful to the BGI (Bureau Gravimétrique international) for their kind collaboration by providing EGM2008 data used in this paper as well as the anonymous reviewers for their constructive reviews which improved the quality of our manuscript.

\section{Competing interests}

The authors declare that they have no competing interests.

\section{Ethics approval and consent to participate}

Not applicable.

\section{Publisher's Note}

Springer Nature remains neutral with regard to jurisdictional claims in published maps and institutional affiliations.

Received: 14 December 2017 Accepted: 4 March 2018

Published online: 13 March 2018

\section{References}

Abate Essi JM (2010) Etude gravimétrique de la limite craton du CongoPanafricain au Centre-Cameroun: implications géodynamiques et intérêt métallogénique. Mem Master, Univ Yaoundé 1

Abate Essi JM, Marcel J, Yene AJQ, Diab AD, Fita DE, Mbossi EF, Mvondo OJ, Penaye J (2017) Interpretation of gravity data derived from the Earth Gravitational Model EGM2008 in the Center-North Cameroon: structural and mining implications. Arab J Geosci 10:130-132. https://doi. org/10.1007/s12517-017-2919-y

Amante C, Eakins BW (2008) ETOPO1 1 arc-minute global relief model: procedures, data sources and analysis. National Geophysical Data Center, NESDIS, NOAA, U.S. Department of Commerce, Boulder

Ballentine CJ, Lee DC, Halliday AN (1997) Hafnium isotopic studies of the Cameroon line and new HIMU paradoxes. Chem Geol 139:111-124. https:// doi.org/10.1016/S0009-2541(97)00028-4

Benkhelil J (1986) Structure and geodynamics evolution of the intracontinental Benue-Trough (Nigeria) thesis, University of Nice, Pub Elf (Nigeria) Ltd

Blakely RJ, Simpson RW (1986) Approximating edges of sources bodies from magnetic or gravity anomalies. Geophysics 51:1494-1498

Browne SE, Fairhead JD (1983) Gravity study of the Central African Rift System: a model of continental disruption 1. The Ngaoundere and Abu Gabra rifts. Tectonophysics 94:187-203. https://doi. org/10.1016/0040-1951(83)90016-1
Champetier de Ribes G, Aubague M (1956) Carte géologique de reconnaissance au 1/500000ème. Publication de la Direction des Mines et de la Géologie du Cameroun, Imprimerie de Rébon, Paris

Champetier de Ribes G, Reyre D (1959) Carte géologique de reconnaissance du Cameroun au 1/500000ème Feuille Yaoundé-Ouest, avec notice explicative. Imprimerie de Rébon, Paris

Collignon L (1968) Gravimétrie de reconnaissance de la République Fédérale du Cameroun. O.R.S.T.O.M, Paris

Déruelle B, Moreau C, Nkoumbou C, Kambou R, Lissom J, Njonfang E, Ghogomu RT, Nono A (1991) The Cameroon Line: a review. In: Kampunzu AB, Lubala RT (eds) Magmatism in extensional structural settings. Springer, Berlin, pp 274-327

Déruelle B, Ngounouno I, Demaiffe D (2007) The 'Cameroon Hot Line' (CHL): a unique example of active alkaline intraplate structure in both oceanic and continental lithospheres. C R Geosci 339(9):589-600. https://doi. org/10.1016/j.crte.2007.07.007

Dumort JC (1968) Carte géologique de reconnaissance de Douala Ouest à 1/500 000ème. Publication de la Direction des Mines et de la Géologie du Cameroun, Imprimerie Nationale, Yaoundé Cameroun

Dunlop HM, Fitton JD (1979) A K-Ar and Sr-Isotope Study of the Volcanic rocks of 720 the Island of Principe, West Africa-evidence for Mantle heterogeneity Beneath the 721 Gulf of Guinea. Contrib Mineral Petrol 71:125-131

Everaerts M, Mansy JL (2001) Le filtrage des anomalies gravimétriques, une clé pour une compréhension des structures tectoniques du Boulonnais et de I'Artois (France). Bull Soc Géol 172(3):267-274

Eyike A, Werner SC, Ebbing J, Manguelle-Dicoum E (2010) On the use of global potential field models for regional interpretation of the west and central African rift system. Tectonophysics 492:25-39. https://doi.org/10.1016/j. tecto.2010.04.026

Fan Z, Huang X, Tan L, Yang X, Zhang H, Zhou D, Liu Q, Cao B (2014) A study of iron deposits in the Anshan area, China based on interactive inversion technique of gravity and magnetic anomalies. Ore Geol Rev 57:618-627. https://doi.org/10.1016/j.oregeorev.2013.09.017

Fitton JG (1980) The Benue trough and Cameroon line-a migration rift system in West Africa. Earth Planet Sci Lett 51:132-138

Fitton JG (1983) Active versus passive continental rifting: evidence from the West African rift system. Tectonophysics 94:473-481. https://doi. org/10.1016/0040-1951(83)90030-6

Fitton JG, Dunlop HM (1985) The Cameroon Line, West Africa and its bearing on the origin of oceanic and continental alkali basalt. Earth Planet Sci Lett 72:23-38

Grauch VJS, Cordell L (1987) Limitations of determining density or magnetic boundaries from the horizontal gradient of gravity or pseudogravity data. Geophysics 22:359-383. https://doi.org/10.1190/1.1442236

Hadhemi B, Fatma H, Ali K, Mohamed G (2016) Subsurface structure of Teboursouk and El Krib plains (dome zone, northern Tunisia) by gravity analysis. Afr Earth Sci 119:78-93. https://doi.org/10.1016/j.jafrearsci.2016.03.015

Hedberg JD (1968) A geological analysis of the cameroon trend. Ph.D. thesis, University of Princeton, Princeton

Jacobsen BH (1987) A case for upward continuation as a standard separation filter for potential-field maps. Geophysics 52:390-398. https://doi. org/10.1190/1.1442378

Jaffal M, El Goumi N, Kchikach A, Tahar A, Khattach D, Manar A (2010) Gravity and magnetic investigations in the Haouz basin, Morocco: interpretation and mining implications. J Afr Earth Sci 58:331-340. https://doi. org/10.1016/j.jafrearsci.2010.03.012

Keating PB (1998) Weighted Euler deconvolution of gravity data. Geophysics (63):1595-1603. https://doi.org/10.1190/1.1444456

Koch P (1953) Carte géologique de reconnaissance à l'échelle du 1/500000: Levés effectués de 1949-1950 avec notice explicative sur la feuille Banyo. Publication de la Direction des Mines et de la Géologie du Cameroun, mprimerie Nationale, Yaoundé Cameroun

Koch FW, Wiens DA, Nyblade AA, Shore PJ, Tibi R, Ateba B, Tabod CT, Nnange JM (2012) Upper-mantle anisotropy beneath the Cameroon Volcanic Line and Congo Craton from shear wave splitting measurements. Geophys J Int 190:75-86

Le Maréchal A (1976) Géologie et géochimie des sources thermominérales du Cameroun, Travaux et documentation de l'ORSTOM, n8 59

Lee DC, Halliday AN, Fitton JG, Poli G (1994) Isotopic variations with distance and time in the volcanic islands of the Cameroon Line-evidence for a mantle plume origin. Earth Planet Sci Lett. 123:119-138 
Lockwood JP, Rubin M (1989) origin and age of the Lake Nyos maar, Cameroon. J Volcanol Geotherm Res 39:117-124

Marcel J, Njandjock NP, Tabob CT, Manguelle-Dicoum E (2010) Moho depth estimates for the Cameroon Volcanic Line from gravity data. Int J Econ Environ Geol 1:17-20

Marcel J, Abate Essi JM, Njandjock NP, Ngatchou HE, Oyoa V, Tabod CT, Manguelle-Dicoum E (2016) Structure of the crust beneath the southwestern Cameroon, from gravity data analysis. Int J Geol 7:991-1008. https://doi. org/10.4236/ijg.2016.78075

Maurizot P, Abessolo A, Feybesse JL, Johan V, Lecomte P (1986) Etude et prospection minière du sud-ouest Cameroun. Synthèse des travaux de 1978 à 1985. B.R.G.M. Report 85 CMR 066

Moreau C, Regnoult JM, Deruelle B, Robineau B (1987) A new tectonic model for the Cameroon Line, Central-Africa. Tectonophysics 141:317-334. https://doi.org/10.1016/0040-1951(87)90206-X

Ngako V (1986) Evolution métamorphique et structurale de la bordure Sud-Ouest de la «Série de Poli» segment camerounais de la Chaine Panafricaine. Centre Amoricain d'Etude Structurale des Socles, mem et doc. University of Rennes, Rennes

Ngako V, Jegouzo P, Nzenti JP (1991) Le cisaillement centre Camerounais. Rôle structural et géodynamique dans l'orogenése panafricaine. CR Acad Sci Paris 313:457-463

Ngako V, Njonfang E, Tongwa AF, Affaton P, Metuk NJ (2006) The North-South Paleozoic to Quaternary trend of alkaline magmatism from Niger-Nigeria to Cameroon: complex interaction between hotspots and Precambrian faults. J Afr Earth Sci 45(3):241-256. https://doi.org/10.1016/j. jafrearsci.2006.03.003

Ngako V, Affaton P, Njonfang E (2008) Pan-African tectonics in northwestern Cameroon: implication for the history of western Gondwana. Gondwana Res 14:509-522. https://doi.org/10.1016/j.gr.2008.02.002

Ngatchou HE, Liu G, Tabod CT, Wang Y, Kamguia J, Nguiya S, Tiedeu A, Ke X (2014) Crustal structure beneath Cameroon from EGM2008. Geod Geodyn 5(1):1-7. https://doi.org/10.3724/SP.J.1246.2014.01001

Ngoumou PC, Ndougsa-Mbarga T, Assembe SP, Kofane TC (2014) Evidence of iron mineralization channels in the Messondo area (Centre-Cameroon) using geoelectrical (DC \& IP) methods: a case study. Int J Geoinf 5:346-361

Ngounouno I, Déruelle B, Demaiffe D (2000) Petrology of the bimodal Cenozoic volcanism of the Kapsiki plateau (northernmost Cameroon, Central Africa). J Volcanol Geotherm Res 102:21-44

Nguene FR, Tamfu S, Loule JP, Ngassa C (1992) Paleoenvironments of the Douala and Kribi/Campo subbasins in Cameroon, West Africa. In: Curnelle R (ed) Géologie Africaine. 1er Colloque de Stratigraphie et de Paléogéographie des Bassins Sédimentaires Ouest-Africains. Zème Colloque Africain de Micropaléontologie, 6-8 Mai 1991, Libreville, Gabon. Bulletin du Centre de Recherche. Exploration-Production, Elf Aquitaine (13):129-139

Ngwa CN, Hanstee TH, Devey CW, Van der Zwan FM, Suh CE (2017) Origin and evolution of primitive melts from the Debunscha Maar, Cameroon: consequences for mantle source heterogeneity within the Cameroon Volcanic Line. Lithos 288-289:326-337. https://doi.org/10.1016/j. lithos.2017.06.028

Njonfang E, Ngako V, Moreau C, Affaton P, Diot H (2008) Restraining bends in high temperature shear zones: "The Central Cameroon Shear Zone", Central Africa. J Afr Earth Sci 52:9-20. https://doi.org/10.1016/j. jafrearsci.2006.03.003

Nkono C, Féménias O, Demaiffe D (2014) Geodynamic model for the development of the Cameroon Hot Line (Equatorial Africa). J Afr Earth Sci 100:626-633. https://doi.org/10.1016/j.jafrearsci.2014.08.008

Nkouathio DG, Kagou Dongmo A, Bardintzeff JM, Wandji P, Bellon H, Pouclet A (2008) Evolution of volcanism in graben and horst structures along the Cenozoic Cameroon Line (Africa): implications for Tectonic evolution and mantle source composition. Mineral Petrol 94:287-303. https://doi. org/10.1007/s00710-008-0018-1

Nnange JM, Ngako V, Fairhead JD, Ebinger CJ (2000) Depths to density discontinuities beneath the Adamawa Plateau Region, Central Africa, from spectral analyses of new and existing gravity data. J Afr Earth Sci 30:887-901

Noutchogwe TC (2010) Investigation géophysique dans la région de l'Adamaoua par les méthodes gravimétriques et magnétiques: implications structurales et hydrogéologiques. Ph.D. thesis, University of Yaounde I
Nsifa KE, Tchameni R, Nédélec A, Siqueira R, Pouclet A, Bascou J (2013) Structure and petrology of Pan-African nepheline syenites from the South West Cameroon; Implications for their emplacement mode, petrogenesis and geodynamic significance. J Afr Earth Sc 87:44-58. https://doi. org/10.1016/j.jafrearsci.2013.07.008

Pavlis NK, Holmes SA, Kenyon SC, Factor JK (2012) The development and evaluation of the Earth Gravitational Model 2008 (EGM2008). J Geophys Res 117:1-38

Peronne Y (1969) Carte géologique de reconnaissance de Wum-Banyo à 1/500000. Publication de la Direction des Mines et de la Géologie du Cameroun, Paris

Philips JD (1998) Processing and interpretation of aeromagnetic data for the Santa Cruz Basin—Patahonia mountains area, South-Central Arizona. U.S. Geological Survey Open-File Report, Arizona, pp 02-98

Popoff M (1987) Evolution des bassins et des environnements sédimentaires crétacés du fossé de la Bénoué (Nigéria). Bull Centre Rech Exploit Prod Elf Aquitaine 11(1):174-177

Pouclet A, Tchameni R, Mezger K, Vidal M, Nsifa EN, Shang CK, Penaye J (2007) Archaean crustal accretion at the northern border of the Congo craton (South Cameroon); the charnockite-TTG link. Bull Soc Géol Fr 178:331-342

Poudjom-Djomani YH (1993) Apport de la Gravimétrie à l'étude de la Lithosphère continentale et implications géodynamiques. Etude d'un bombement intraplaque: Le massif de l'Adamaoua (Cameroun). Thèse de Doct/Ph.D., Univ Paris-Sud, Centre d'Orsay. № d'ordre 2798, Ed. ORSTOM

Poudjom-Djomani YH, Boukeke DB, Legeley-Padovani A, Nnange JM, AtebaBekoa Albouy Y, Fairhead JD (1996) Levés gravimétriques de reconnaissance du Cameroun. ORSTOM, Paris

Regnoult JM (1986) Synthèse Géologique du Cameroun. Ministère des Mines et de l'Energie, Yaoundé, p 119

Reid AB, Allsop JM, Granser H, Millet AJ, Somerton IW (1990) Magnetic interpretation in three dimensions using Euler deconvolution. Geophysics 55:180-191

Tamen J, Nkoumbou C, Mouafo L, Reusser E, Tchoua FM (2007) Petrology and geochemistry of monogenetic volcanoes of the Barombi Koto volcanic field (Kumba graben, Cameroon volcanic line): implications for mantle source characteristics. CR Acad Sci Paris 339:799-809

Tchameni R, Lerouge C, Penaye J, Cocherie A, Milesi JP, Toteu SF, Nsifa NE (2010) Mineralogical constraint for metamorphic conditions in a shear zone affecting the Archean Ngoulemakong tonalite, Congo Craton (Southern Cameroon) and retentivity of U-Pb SHRIMP zircon dates. J Afr Earth Sci 58:67-80. https://doi.org/10.1016/j.jafrearsci.2010.01.009

Tchoua FM (1974) Contribution à létude géologique et pétrologique de quelques volcans de la «Ligne du Cameroun» (Monts Manengouba et Bambouto). Thèse Doct d'Etat, Univ Clermont-Ferrand, France

Telford WM, Geldart LP, Sheriff RE (1990) Applied geophysics, 2nd edn. Cambridge University Press, Cambridge

Thompson DT (1982) A new technique for making computer-assisted depth estimates from magnetic data. Geophysics 47:31-37

Toteu SF, Michard A, Bertrand JM, Rocci G (1987) U-Pb dating of Precambrian rocks from northern Cameroon, orogenic evolution and chronology of the Pan-African belt of central Africa. Precambrian Res 37:71-87

Toteu SF, Van Schmus RW, Penaye J, Michard A (2001) New U-Pb and Sm-Nd data from north-central Cameroon and its bearing on the pre-Pan-African history of central Africa. Precambrian Res 108:45-73

Toteu SF, Penaye J, Poudjom Djomani Y (2004) Geodynamic evolution of the Pan- African belt in central Africa with special reference to Cameroon. Can J Earth Sci 41:73-85

Van Houten FB (1983) Sirte Basin, northcentral Libya: cretaceous rifting above a fixed mantle hotspot? Geology 11:115-118

Van Schmus WR, Oliveira EP, Da Silva Filho AF, Toteu SF, Penaye J, Guimães IP (2008) Proterozoic links between the Borborema Province, NE Brazil, and the Central African Fold Belt. J Geol Soc (Lond) 294:69-99

Weecksteen G (1957) Carte géologique de reconnaissance à l'échelle du 1/500 000ème, feuille Douala-Est, avec notice explicative. Publication de la Direction des Mines et de la Géologie du Cameroun, Paris 